Pesq. Vet. Bras. 38(4):779-784, abril 2018

\title{
Acute phase proteins in serum and cerebrospinal fluid in healthy cattle: possible use for assessment of neurological diseases ${ }^{1}$
}

\author{
Paula A. Di Filippo ${ }^{2 *}$, Saulo T. Lannes ${ }^{2}$, Marcos A.D. Meireles², \\ Andressa F.S. Nogueira ${ }^{3}$, Luiza M.F. Ribeiro², Flavio A.S. Graça ${ }^{2}$ \\ and Leonardo S. Glória ${ }^{2}$
}

\begin{abstract}
Di Filippo P.A., Lannes S.T., Meireles M.A.D., Nogueira A.F.S., Ribeiro L.M.F., Graça F.A.S. \& Glória L.S. 2018. Acute phase proteins in serum and cerebrospinal fluid in healthy cattle: possible use for assessment of neurological diseases. Pesquisa Veterinária Brasileira 38(4):779-784. Laboratório de Clínicas e Cirurgia Veterinária, Centro de Ciências e Tecnologias Agropecuárias, Universidade Estadual do Norte Fluminense "Darcy Ribeiro", Avenida Alberto Lamego 2000, Campos dos Goytacazes, RJ 28013-602, Brazil. E-mail: pdf@uenf.br

Use of acute-phase proteins (APPs) for assessment of health and disease in animals has increased greatly within the last decade. The objective was to determine the normal concentration of APPs in the serum and cerebrospinal fluid (CSF) of healthy cattle by polyacrylamide gel electrophoresis. Fifty crossbred animals ( $350 \pm 70 \mathrm{~kg}$ of BW and $18 \pm 1.2$ months of age), 25 heifers and 25 steers were used. CSF samples were collected from atlanto-occipital (AO) site and blood samples were obtained from the jugular vein. CSF and serum protein electrophoresis were performed by means of sodium dodecyl sulphate-polyacrylamide gel electrophoresis. Thirty-seven proteins with molecular weights ranging from 7 and $37 \mathrm{kDa}$ were identified in CSF of all animals. These eight were nominally identified with immunoglobulin A and $\mathrm{G}$, celuloplasmin, transferrin, albumin, $\alpha_{1}$-antitripsin, acidic glycoprotein, and haptoglobin. All protein fractions in CSF did not differ between heifers and steers. In sera, 34 proteins with molecular weights between 7 and $244 \mathrm{kDa}$ were identified in heifers and steers. Similar proteins were nominally identified in the sera, but only the CSF presented $\alpha_{1}$-antitripsin. The serum values of acidic glycoprotein and immunoglobulin $\mathrm{G}$ were significantly higher in steers compared with heifers. In conclusion, measurement of CSF acute phase protein concentrations can be useful in diagnosing and monitoring the progression of bovine neurological diseases, perhaps even to guide therapeutic procedures. The CSF electrophoretic profile of healthy cattle does not change depending on gender.
\end{abstract}

INDEX TERMS: Acute phase response, protein, serum, cerebrospinal fluid, cattle, neurological diseases, polyacrylamide gel electrophoresis, cerebrospinal fluid biomarker, neuroinflammation.

RESUMO.- [Proteínas de fase aguda no soro e no líquido cefalorraquidiano de bovinos hígidos: possíveis usos na avaliação de doenças neurológicas.] 0 uso de proteínas de fase aguda (PFAs) para a avaliação da saúde e da doença em animais

\footnotetext{
${ }^{1}$ Received on October 26, 2016.

Accepted for publication on May 9, 2017.

${ }^{2}$ Laboratório de Clínicas e Cirurgia Veterinária (LCCA), Centro de Ciências e Tecnologias Agropecuárias (CCTA), Universidade Estadual do Norte Fluminense "Darcy Ribeiro" (UENF), Avenida Alberto Lamego 2000, Parque Califórnia, Campos dos Goytacazes, RJ 28013-602, Brazil. E-mails: stlannes@yahoo.com.br,marcosadmeireles@yahoo.com.br,f.feitosaribeiro@ gmail.com, flaviograca@uol.com.br, leonardo.gloria@zootecnista.com.br; *Corresponding author: pdf@uenf.br

${ }^{3}$ Universidade Federal do Piauí (UFP), BR-135 Km 3, Bairro Planalto Horizonte, Bom Jesus, PI 64900-000, Brazil. E-mail: dessafsn@yahoo.com.br
}

de produção tem aumentado consideravelmente na última década. 0 objetivo deste estudo foi determinar a concentração normal de PAFs no soro e no líquido cefalorraquidiano (LCR) de bovinos sadios por meio da eletroforese em gel de poliacrilamida. Foram avaliados cinquenta animais mestiços ( $350 \pm 70 \mathrm{~kg}$ de PV e 18 $\pm 1,2$ meses de idade), 25 novilhas e 25 novilhos. As amostras de LCR foram colhidas no espaço atlanto-occipital (AO) e as amostras de sangue obtidas da veia jugular. As PAFs do soro e do LCR foram determinadas através da eletroforese em gel poliacrilamida. Trinta e sete proteínas com pesos moleculares que variaram entre 7 e $37 \mathrm{kDa}$ foram identificadas no LCR de todos os animais, independente do sexo. Estas oito proteínas foram nominalmente identificadas como imunoglobulina A e G, ceruloplasmina, transferrina, 
albumina, $\alpha 1$-antitripsina, glicoproteína ácida, e haptoglobina. As frações de proteínas presentes no LCR não diferiram entre novilhas e novilhos. No soro de machos e fêmeas, 34 proteínas com pesos moleculares entre 7 e $244 \mathrm{kDa}$ foram identificadas. As proteínas do soro foram similarmente identificadas, entretanto a $\alpha 1$-antitripsina foi identificada somente no LCR. Os valores séricos de glicoproteína ácida e imunoglobulina $\mathrm{G}$ foram significativamente mais elevados nas novilhas em comparação aos novilhos. Em conclusão, a determinação das concentrações de proteínas de fase aguda presentes do LCR pode ser útil no diagnóstico e monitoramento da progressão de doenças neurológicas bovinas, talvez possa ainda direcionar procedimentos terapêuticos. 0 perfil eletroforético do LCR de bovinos hígidos não se altera em função do sexo.

TERMOS DE INDEXAÇÃO: Proteínas, resposta de fase aguda, soro, líquido cefalorraquidiano, bovinos, neurologia, eletroforese em gel de poliacrilamida, biomarcadores do líquido cérebro-espinhal, neuroinflamação.

\section{INTRODUTION}

The physiological response to infections, trauma or surgery, stress, neoplasia, immunological disorders and injuries involves local inflammation and the start of events leading to a systemic response, also called acute phase reaction (APR) (Murata et al. 2004, Petersen et al. 2004, Cerón et al. 2005, Ceciliani et al. 2012). This multiplicity of changes is distant from the injury site, and includes fever, leukocytosis and quantitative and qualitative modification of a group of non-structurally related proteins present in blood and other biological fluids, collectively named acute phase proteins (APPs) (Ceciliani et al. 2012).

The APPs consist of "negative" and "positive" proteins that show a decrease and an increase in levels, respectively, in response to challenge. The negative APPs include albumin and transferrin. The positive ones include haptoglobin, C-reactive protein, serum amyloid A, caeruloplasmin, fibrinogen and alpha 1-acid glycoprotein (Murata et al. 2004). Acute phase proteins are primarily produced in the liver (Murata et al. 2004, Petersen et al. 2004, Ceron et al. 2005). However, extrahepatic production of APPs is also possible in most mammalian species (Jacobsen et al. 2006, Di Filippo et al. 2011, 2014a). Some APPs opsonize microorganisms and activate complements, while others scavenge cellular remnants and free radicals or neutralize proteolytic enzymes (Gruys et al. 2005). The proinflammatory cytokines, IL-1, TNFa and IL-6 are the major mediators of APP synthesis by hepatocytes (Petersen et al. 2004, Tizard 2009).

The circulating concentrations of APPs are related to the severity of the disorder and the extent of tissue damage in the affected animal. Therefore, quantification of their concentration can provide diagnostic and prognostic information if proper timing of sampling is assured (Murata et al. 2004). The results of one study found that APPs were eight times more sensitive in the diagnosis and prognosis of inflammatory diseases in animals than leukocyte count (Cerón et al. 2005).

Recent studies have demonstrated an increase in the concentration of APPs in cerebrospinal fluid (CSF) in humans and dogs with neurological diseases and traumatic brain injury. A significant association between high levels of proinflammatory markers in CSF and severity of fatigue, depression, anxiety and cognitive impairment in individuals with Parkinson's disease has been demonstrated (Lindqvist et al. 2013). Another study concluded that CSF APPs estimation is a useful marker to differentiate pyogenic from non-pyogenic meningitis, but it cannot differentiate between tuberculosis and fungal or viral meningitis (Anil Kumar et al. 2010). In turn, it has been demonstrated that the level of APPs is significantly greater in the CSF of dogs with acute spinal cord injury compared with healthy control dogs (Anderson et al. 2015). CSF APPs levels were positively associated with the severity of spinal cord damage and can serve as a prognostic indicator in dogs with intervertebral disc herniation (Roerig et al. 2013).

Therefore, analysis of APPs has become an important tool in the diagnosis, treatment and prognosis of neurological inflammatory diseases in humans as well as domestic animals. In view of the great importance of cattle not only in production of milk and meat, but also transmission of disease to humans, it is advisable to determine APP levels in the CSF of healthy animals. The aim of this study was to determine the concentration of APPs in the CSF of healthy heifers and steers by polyacrylamide gel electrophoresis.

\section{MATERIALS AND METHODS}

The protocol used in this experiment was in accordance with the Brazilian College of Animal Experimentation (COBEA - Colégio Brasileiro de Experimentação Animal) guidelines and was approved by the Ethics Committee for Tests with Animals (CEUA - Comissão de Ética e Bem Estar Animal) of the Universidade Estadual do Norte Fluminense Darcy Ribeiro, Campos dos Goytacazes/RJ, Brazil (protocol number 291).

Fifty crossbred cattle ( 25 heifers and 25 steers) with average age of $18 \pm 1.2$ months and weighing $350 \pm 70 \mathrm{~kg}$ were carefully selected and included in the study. The animals were raised in pastures (Brachiaria decumbens) on the same farm. They had ad libitum access to water and mineral salt and received commercial feed containing $16 \%$ crude protein ( $\mathrm{min}$ ). The animals were immunized against clostridioses (Poli-Star ${ }^{\circledR}$, Vallé), rabies (Raivacel Multi ${ }^{\circledR}$, Vallé) and foot and mouth disease (Bovicel ${ }^{\circledR}$, Vallé). The animals were examined on the day before the study, with focus on the neurological system. Inclusion criteria were normal findings in clinical examination, complete blood count (MS4 Vet Hematology Analyzer, Melet Schloesing Laboratoires, France), and biochemical parameters (Labquest, CELM, model E-225-D, Brazil).

Cerebrospinal fluid (CSF) fluid was collected at the atlanto-occipital (AO) site using a $14 \mathrm{G}$ catheter with the animals standing positioned in a head gate. Before collection, $0.2 \mathrm{mg} \mathrm{kg}^{-1}$ of BW of anesthetic ( $2 \%$ xylaxine, Syntec) was administered intramuscularly. At the same time, a skin area measuring approximately $20 \times 20 \mathrm{~cm}$ was clipped immediately caudal to the external occipital protuberance $110 \mathrm{~cm}$ on each side of the midline). Following aseptic preparation of the site, local anesthesia was performed (10mL, 2\% lidocaine, Bravet). CSF samples were stored at $-20^{\circ} \mathrm{C}$ until analysis. From each animal, blood samples $(5 \mathrm{~mL})$ were collected via jugular vein venipuncture with a Vacutainer (BD) into plain tubes. Sera samples were collected after centrifugation at $2500 \mathrm{~g}$ at $8^{\circ} \mathrm{C}$ for $10 \mathrm{~min}$ and subsequently stored at $-20^{\circ} \mathrm{C}$ until assayed.

Total protein levels in serum (g/dl) and CSF (mg/L) were measured according to the biuret protein assay and using a set of diagnostic reagents (Labtest, Sistema de Diagnósticos Ltda., Lagoa Santa, Brazil) and spectrophotometric readings (Biosystem ${ }^{\circledR}$ - BTS-350). After protein determinations, the samples of CSF were submitted to lyophilization (LioTop L-101).

Protein fractions were determined by sodium dodecyl sulfate polyacrylamide gel electrophoresis (SDS-PAGE), according to the technique described by Laemmli (1970). Molecular weights and 
concentrations of protein fractions were determined by computed videodensitometry (CS 9000, Shimadzu Corp., Kyoto, Japan). Reference markers (Sigma Chemical Co., St Louis, USA) were used to characterize proteins, with molecular weights of $29,45,66,97.4$, 116 , and $205 \mathrm{kDa}$. Also, electrophoretic migration of proteins was compared with that of pure proteins including albumin, transferrin, haptoglobin, ceruloplasmin, IgA, IgG, and acidic glycoprotein.

The values obtained were compiled and presented as means \pm SEM. The data were submitted to ANOVA with repeated measures. Significant means were compared using the F-test with significance of $P<0.01$.

\section{RESULTS}

Thirty-seven proteins with molecular weights between 7 and $37 \mathrm{kDa}$ were identified in cerebrospinal fluid (CSF) of heifers and steers. CSF levels of proteins of $169 \mathrm{kDa}$ (immunoglobulin A), $104 \mathrm{kDa}$ (celuloplasmin), 85kDa (immunoglobulin G), $77 \mathrm{kDa}$ (transferrin), $64 \mathrm{kDa}$ (albumin), $58 \mathrm{kDa}\left(\alpha_{1}\right.$-antitripsin), $39 \mathrm{kDa}$ (acidic glycoprotein), and $43 \mathrm{kDa}$ (haptoglobin) were nominally identified (Table 1). All protein fractions in CSF did not differ between heifers and steers.

In sera, 34 proteins with molecular weights between 7 and $244 \mathrm{kDa}$ were identified in all animals. Serum levels of proteins of $105 \mathrm{kDa}$ (celuloplasmin), 171kDa (immunoglobulin A), 85kDa (immunoglobulin G), 77kDa (transferrin), 62kDa (albumin), $41 \mathrm{kDa}$ (haptoglobin), and 39kDa (acidic glycoprotein) were nominally identified (Table 2). The serum values of acidic glycoprotein and immunoglobulin $\mathrm{G}$ were significantly higher in steers compared with the values in heifers.

Table 1. Cerebrospinal fluid protein concentrations (mean \pm SEM), determined by sodium dodecyl sulphate-polyacrylamide gel electrophoresis, in crossbred heifers and steers

\begin{tabular}{lccc}
\hline \multicolumn{1}{c}{ Protein } & \multicolumn{2}{c}{ Cattle } & \multirow{2}{*}{ Value of $P$} \\
\cline { 2 - 3 } \multicolumn{1}{c}{ Heifl) } & Heifers & Steers & \\
\hline Total serum protein & $12.2 \pm 1.04$ & $14.7 \pm 1.02$ & 0.09 \\
Albumin & $5.29 \pm 0.45$ & $7.08 \pm 0.74$ & 0.04 \\
Ceruloplasmin & $0.03 \pm 0.00$ & $0.03 \pm 0.00$ & 0.79 \\
Transferrin & $0.54 \pm 0.07$ & $0.53 \pm 0.07$ & 0.91 \\
Haptoglobin & $0.23 \pm 0.08$ & $0.21 \pm 0.08$ & 0.85 \\
Acid glycoprotein & $0.21 \pm 0.04$ & $0.17 \pm 0.03$ & 0.47 \\
Immunoglobulin A & $0.07 \pm 0.02$ & $0.11 \pm 0.02$ & 0.19 \\
Immunoglobulin G & $3.05 \pm 0.31$ & $3.76 \pm 0.30$ & 0.11 \\
$\alpha 1$-antitripsina & $0.27 \pm 0.05$ & $0.29 \pm 0.06$ & 0.75
\end{tabular}

Different letters (A and B) in the same line indicate differences between groups $(P<0.01)$.

Table 2. Serum protein concentrations (mean \pm SEM), determined by sodium dodecyl sulphate-polyacrylamide gel electrophoresis, in crossbred heifers and steers

\begin{tabular}{|c|c|c|c|}
\hline \multirow{2}{*}{$\begin{array}{l}\text { Protein } \\
(\mathrm{mg} / \mathrm{dl})\end{array}$} & \multicolumn{2}{|c|}{ Cattle } & \multirow{2}{*}{$\begin{array}{c}\text { Value } \\
\text { of } P\end{array}$} \\
\hline & Heifers & Steers & \\
\hline Total serum protein & $8982.5 \pm 419.1$ & $8488.7 \pm 166.3$ & 0,28 \\
\hline Albumin & $5142.1 \pm 157.4 \mathrm{~A}$ & $5021.7 \pm 98.8 \mathrm{~A}$ & 0.52 \\
\hline Ceruloplasmin & $11.00 \pm 0,81 \mathrm{~A}$ & $13.96 \pm 1.46 \mathrm{~A}$ & 0.08 \\
\hline Transferrin & $335.60 \pm 22.01 \mathrm{~A}$ & $267.54 \pm 22.01 \mathrm{~A}$ & 0.03 \\
\hline Haptoglobin & $9.44 \pm 1.44 \mathrm{~A}$ & $7.65 \pm 0.92 \mathrm{~A}$ & 0.303 \\
\hline Acid glycoprotein & $13.42 \pm 0.73 \mathrm{~A}$ & $7.98 \pm 0.73 \mathrm{~B}$ & 0.00 \\
\hline Immunoglobulin A & $174.90 \pm 17.81 \mathrm{~A}$ & $138.60 \pm 17.81 \mathrm{~A}$ & 0.15 \\
\hline Immunoglobulin G & $2799.36 \pm 95.162 \mathrm{~A}$ & $2070.74 \pm 95.162 \mathrm{~B}$ & 0.00 \\
\hline
\end{tabular}

\section{DISCUSSION}

The serum electrophoretic profile values obtained were similar to those described in the literature for healthy cattle of the same age range (Fagliari et al. 2007, Simplício et al. 2013, Sampaio et al. 2015). The CSF profile has not yet been determined for bovines, so no comparative data are available.

The proteinogram of the cerebrospinal fluid (CSF) of the steers and heifers was similar to the serum subfractionation, except for $\alpha 1$-antitripsin, which was only present in the CSF. Different body fluids can have similar electrophoretic profiles (Kaneko et al. 2008). However, in cattle, the serum levels of $\alpha 1$-antitripsin can be so low that their systemic detection is difficult. Similar findings were described by Fagliari et al. (2007) and Sampaio et al. (2015).

The identification and quantification of $\alpha 1$-antitripsin in the CSF of the animals can be related to the local synthesis of this APP by the glial cells or other tissues of the central nervous system (CNS) (Johanson et al. 2008). Approximately $20 \%$ of the proteins present in the CSF are produced locally, with the other $80 \%$ coming from the blood. The plasma proteins selectively cross the blood-brain barrier before reaching the CSF (Johanson et al. 2008, Kaneko et al. 2008).

The APPs are often called blood proteins because they are primarily synthesized by the hepatocytes, and their production is part of the acute phase response (Ceciliani et al. 2012). However, it has been demonstrated that APPs can be produced by many other tissues and cells (Jacobsen et al. 2006, Di Filippo et al. 2014a, 2014b). Under normal physiological conditions, the production of amyloid A (McDonald et al. 2001) and $\alpha 1$ acid glycoprotein (Ceciliani et al. 2005) by the epithelial cells of the mammary gland of healthy bovines has been reported. Increases in the local expression of $\mathrm{Hb}$ were observed after intramammary infusion of LPS (Hiss et al. 2004) and infection by Escherichia coli (Buitenhuis et al. 2011). Hb was also detected in the ovaries and oviducts of milk cows in luteal and non-luteal phases of the estrous cycle (Lavery et al. 2003).

The local extrahepatic production of APPs appears to occur in disseminated form, mobilizing different tissues simultaneously with the liver (Gruys et al. 2005). The mechanism probably plays the role of counteracting the proinflammatory effects inside the injured tissue (Ceciliani et al. 2012). Measurement of the local levels of APPs, by providing information on the inflammatory/infectious status of an organ of interest, increases the diagnostic precision (Jacobsen et al. 2006). In one study, an increase was noted in the concentration of transferrin (Tf) in the CSF of people suffering from restless leg syndrome (RLS). However, there was no change in the serum values of Tf (Mizuno et al. 2005). Similar results have been observed in people with multiple sclerosis (Khalil et al. 2014). Tf is one of the main carriers of iron in CNS, in humans acting as an important marker of neurodegenerative diseases (Murata et al. 2004).

Haptoglobin (Hp) is one of the most plentiful APPs in bovines (Murata et al. 2004). Hp binds to free hemoglobin, which is toxic and proinflammatory, and in the plasma, it reduces the oxidative damages associated with hemolysis (Yang et al. 2003). It has an inhibitory effect on the chemotaxis of granulocytes and on phagocytosis, as well as bactericidal activity. It can also inhibit the proliferation of mast cells (El-Ghmati et al. 2002), impede the spontaneous maturation of 
Langerhans cells (Xie et al. 2000) or suppress the proliferation of T cells (Arredouani et al. 2003).

Increases in blood levels of Hp have been reported in cattle with mastitis, hepatic abscesses, pyometra, traumatic reticulitis and abomasal displacement (Eckersall \& Conner 1988, Ceciliani et al. 2012). On the other hand, inflammation caused by the bovine pestivirus did not result production of detectable levels of $\mathrm{Hp}$ (Spooner \& Miller 1971). This is similar to the acute phase response observed in other mammals, in which its production is not stimulated by viral diseases (Eckersall \& Conner 1988). Based on this context, the determination of the concentration of $\mathrm{Hp}$ in the CFS was ineffective to diagnose viral meningitis in humans. However, this measurement was found to be effective to diagnose bacterial meningitis (Noris-García et al. 1999) and Parkinson's disease (Costa et al. 2011).

In dogs, an increase of Hp in the CFS was demonstrated in animals with naturally occurring intervertebral disc herniation (IVDH) compared to healthy dogs (Anderson et al. 2015). In the same study, dogs with severe spinal cord injury showed significantly higher concentration of $\mathrm{Hp}$ in the CSF than animals with slight to moderate injuries. However, no correlation was found between the Hp concentration in the CSF and the motor, posture or sensory results. Hp was considered the most important APP of the CSF after injury associated with IVDH in the dogs studied (Anderson et al. 2015). In humans, the concentration of Hp in the CSF was also found to be significantly higher after traumatic brain injury. Hp is $\alpha$-2-glicoprotein produced by the liver and oligodendroglia in response to IL-6 and other proinflammatory cytokines (Yang et al. 2013). Therefore, in the presence of traumatic brain injuries, intracranial hemorrhages and autoimmune encephalitis, it is believed that Hp exerts neuroprotective effects by binding with free hemoglobin (Zhao et al. 2009).

Ceruloplasmin is primarily synthesized in the liver, but studies have demonstrated that it can also be synthesized by neurons and that lipopolysaccharides (LPS) can induce its extra-hepatic synthesis (Murata et al. 2004, Anil Kumar et al. 2010). Increases and significant concentrations of ceruloplasmin were found in the CSF of people suffering from pyogenic meningitis. However, no alterations were observed in the ceruloplasmin concentration in the CSF of people with non-pyogenic meningitis (Anil Kumar et al. 2010). The measurement of ceruloplasmin in the CFS also was found to enable early identification of neurodegenerative diseases such as Parkinson's disease (Costa et al. 2011). A massive increase of apolipoprotein E (Apo-E), a biomarker used to diagnose Alzheimer's disease, was found in the CSF of cattle with bovine spongiform encephalopathy (BSE), contributing to the ante-mortem diagnosis of that disease (Hochstrasser et al. 1997).

A positive correlation was observed between the ceruloplasmin concentration in the CSF and the severity of spinal cord injuries in dogs with IVDH (Anderson et al. 2015). Ceruloplasmin was also correlated with the concentration of total proteins in the CSF, signaling rupture of the brain-blood barrier. Similar correlations between APPs of the CSF and the severity of injuries have been found in the case of numerous central nervous system affections in humans, including traumatic brain injury, Alzheimer's disease (Yarchoan et al. 2013) and autoimmune encephalitis (Wang et al. 2013). Another study demonstrated a significant increase in the ceruloplasmin concentration in the CSF of dogs with steroid-responsive meningitis-arteritis (SRMA) compared to healthy animals (Bathen-Noethen et al. 2008). According to the authors, the high concentration of ceruloplasmin in the CSF might have originated from a subarachnoid hemorrhage or the intrathecal production of ceruloplasmin by the leukocytes. Dogs with meningioma and hemangiosarcoma also presented significant increase of ceruloplasmin in the CSF due to changes in the blood-brain barrier and hemorrhages (Gabor \& Vanderstichel 2006).

Ceruloplasmin is an iron oxide containing copper, able to oxidize toxic ferrous iron, transforming it into nontoxic ferric iron. It protects the issues from lesions triggered by iron-mediated free radicals and is involved in many antioxidant and cytoprotective activities (Gruys et al. 2005). It can also act as an anti-inflammatory agent by reducing the number of neutrophils adhered to the endothelium and by removing peroxides (Ceciliani et al. 2012). In cattle, the increase in serum ceruloplasmin is related to inflammatory processes with tissue damages (photosensitization). The reduction of its concentration, however, is associated with metabolic factors like malnutrition and hepatic and renal diseases that affect its production and excretion, respectively (Fagliari et al. 2007).

In cattle $\alpha 1$-acid glycoprotein ( $\alpha 1$-GPA) is a clinically important APP and has been used to monitor affections such as pericarditis, arthritis, mastitis, pneumonia and babesiosis (Murata etal. 2004). Its concentration generally rises more slowly, but remains high for a longer period. Therefore, its measurement can be useful to establish the acute or chronic evolution of different ailments (Petersen et al. 2004, Cerón et al. 2005).

In this study, the steers presented higher serum levels of $\alpha 1$-GPA than the heifers. These differences can be associated with stress (Murata et al. 2004), ingestion or not of colostrum (Orro et al. 2008) and birth from multiparous or primiparous cows. Calves from primiparous cows generally present lower serum concentration of $\alpha 1$-GPA than those from multiparous cows (Rocha et al. 2013). There are no reports of $\alpha 1-\mathrm{GPA}$ levels in the CSF of cattle, but $\alpha 1$-GPA is considered a sensitive marker for bacterial meningitis in pigs and rabbits (Itoh et al. 1993). It is believed that $\alpha 1$-GPA levels in the CSF rise for the purpose of inhibiting TNF- $\alpha$, the main cytokine involved in this type of infection (Itoh et al. 1993). Increases in the levels of $\alpha 1$-GPA in the CSF were also described in people suffering from neurodegenerative diseases like Alzheimer's disease (Roher et al. 2009).

Among the immunoglobulins, IgG and IgA have been detected in electrophoretic band shifts. In livestock, the function of IgA in the immune response has not been totally elucidated. Nevertheless, IgA appears to be related to an inflammatory stimulation, acting as a second line of defense in the elimination of pathogens that have penetrated through the surface mucous barrier (Snoeck et al. 2006). IgA can also act as a secretory antibody within the intestinal tract and lungs, able to neutralize viruses and prevent adherence of bacterial pathogens to target tissues (Di Filippo et al. 2011).

We observed a difference in the serum levels of IgG in the steers and heifers. These findings can be related to the animal's weight at birth, calving age of the cow, milking management, udder characteristics and stress (Fagliari et al. 2007). In another study, increased concentration of IgG was 
observed In the CSF of humans with tuberculosis meningitis. The results were associated with the increased permeability of the blood-brain barrier or intrathecal production, triggered by an oligoclonal reaction (Sardella et al. 2010).

\section{CONCLUSIONS}

We believe that the measurement of cerebrospinal fluid (CSF) acute phase protein concentrations can be useful in diagnosing and monitoring the progression of bovine neurological diseases or traumas, perhaps even to guide therapeutic procedures.

The CSF electrophoretic profile of young cattle does not change based on sex.

Acknowledgements.- We would like to thank Dr. J.J. Fagliari for his assistance with data analysis.

\section{REFERENCES}

Anderson K.M., Welsh C.J., Young C., Levine G.J., Kerwin S.C., Boudreau C.E., Reyes I., Mondragon IV A., Griffin J.F., Cohen N.D. \& Levine J.M. 2015. Acute phase proteins in cerebrospinal fluid from dogs with naturally-occurring spinal cord injury. J. Neurotrauma 32(21):1658-1665. http://dx.doi. org/10.1089/neu.2015.3895. PMid:26186466.

Anil Kumar T., Punith K., Santoosh R., Ravi Kumar V.N.R., Medha Y.R. \& Sudhir U. 2010. Significance of cerebrospinal fluid c-reactive protein level in pyogenic and non-pyogenic meningitis in adults. J. Indian Acad. Clin. Med. 11:112-115.

Arredouani M., Matthijs P., Van Hoeyveld E., Kasran A., Baumann H., Ceuppens J.L. \& Stevens E. 2003. Haptoglobin directly affects T cells and suppresses Thelper cell type 2 cytokine release. Immunology 108(2):144-151. http:// dx.doi.org/10.1046/j.1365-2567.2003.01569.x. PMid:12562322.

Bathen-Noethen A., Carlson R., Menzel D., Mischke R. \& Tipold A. 2008. Concentrations of acute-phase proteins in dogs with steroid responsive meningitis-arteritis. J. Vet. Intern. Med. 22(5):1149-1156. http://dx.doi. org/10.1111/j.1939-1676.2008.0164.x. PMid:18691368.

Buitenhuis B., Rontved C.M., Edwards S.M., Ingvartsen K.L. \& Sorensen P. 2011. In depth analysis of genes and pathways of the mammary gland involved in the pathogenesis of bovine Escherichia coli-mastitis. BMC Genomics 12(1):130. http://dx.doi.org/10.1186/1471-2164-12-130. PMid:21352611.

Ceciliani F., Ceron J.J., Eckersall P.D. \& Sauerwein H. 2012. Acute phase proteins in ruminants. J. Proteomics 75(14):4207-4231. http://dx.doi. org/10.1016/j.jprot.2012.04.004. PMid:22521269.

Ceciliani F., Pocacqua V., Provasi E., Comunian C., Bertolini A., Bronzo V., Moroni P. \& Sartorelli P. 2005. Identification of the bovine alpha 1-acid glycoprotein in colostrum and milk. Vet. Res. 36(5-6):735-746. http:// dx.doi.org/10.1051/vetres:2005029. PMid:16120249.

Cerón J.J., Eckersall P.D. \& Martínez-Subiela S. 2005. Acute phase proteins in dogs and cats: current knowledge and future perspectives. Vet. Clin. Pathol. 34(2):85-99. http://dx.doi.org/10.1111/j.1939-165X.2005.tb00019.x. PMid:15902658.

Costa A.G., Gago M.F. \& Garrett C. 2011. Cerebrospinal fluid biomarkers for the early diagnosis of Parkinson's disease. Acta Médica Portuguesa 24(Suppl.4):761-768. PMid:22863482.

Di Filippo P.A., Gomes F.R., Mascarenhas L.S., Almeida A.J. \& Rodrigues A.B.F. 2014a. Serum and peritoneal protein profile of horses subjected to orchiectomy. Ciência Rural 44:2221-2227.

Di Filippo P.A., Nogueira A.F.S. \& Santana A.E. 2011. Determination of serum haptoglobin, ceruloplasmin, $\alpha 1$-acid glycoprotein, transferrin and $\alpha 1$ antitrypsin in colic horses. Ciência Rural 41(12):2108-2113. http://dx.doi. org/10.1590/S0103-84782011001200012.
Di Filippo P.A., Santos G.C., Graça F.A.S., Nogueira A.F.S., Alves A.E. \& Santana A.E. 2014b. Proteinogram of synovial liquid from healthy equines determined by means of sodium dodecyl sulphate-polyacrylamide gel electrophoresis. Ciência Rural 44:1268-1271.

Eckersall P.D. \& Conner J.G. 1988. Bovine and canine acute phase proteins. Vet. Res. Commun. 12(2/3):169-178. http://dx.doi.org/10.1007/BF00362798. PMid:2460991.

El-Ghmati S.M., Arredouani M., Van Hoeyveld E.M., Ceuppens J.L. \& Stevens E.A.M. 2002. Haptoglobin interacts with the human mast cell line HMC-1 and inhibits its spontaneous proliferation. Scand. J. Immunol. 55(4):352-358. http://dx.doi.org/10.1046/j.1365-3083.2002.01067.x. PMid:11967116.

Fagliari J.J., Passipieri M., Okuda H.Q., Silva S.L. \& Silva P.C. 2007. Serum protein concentrations, including acute phase proteins, in calves with hepatogenous photosensitization. Arq. Bras. Med. Vet. Zootec. 59(6):1355-1358. http:// dx.doi.org/10.1590/S0102-09352007000600001.

Gabor L.J. \& Vanderstichel R.V. 2006. Primary cerebral hemangiosarcoma in a 6-week-old dog. Vet. Pathol. 43(5):782-784. http://dx.doi.org/10.1354/ vp.43-5-782. PMid:16966462.

Gruys E., Toussaint M.J.M., Niewold T.A. \& Koopmans S.J. 2005. Acute phase reaction and acute phase proteins. J. Zhejiang Univ. Sci. B 6(11):1045-1056. http://dx.doi.org/10.1631/jzus.2005.B1045. PMid:16252337.

Hiss S., Mielenz M., Bruckmaier R.M. \& Sauerwein H. 2004. Haptoglobin concentrations in blood and milk after endotoxin challenge and quantification of mammary Hp mRNA expression. J. Dairy Sci. 87(11):3778-3784. http:// dx.doi.org/10.3168/jds.S0022-0302(04)73516-X. PMid:15483161.

Hochstrasser D.F., Frutiger S., Wilkins M.R., Hughes G. \& Sanchez J.C. 1997. Elevation of apolipoprotein $\mathrm{E}$ in the CSF of cattle affected by BSE. FEBS Letters 416(2):161-163.http://dx.doi.org/10.1016/S0014-5793(97)011915. PMid:9369204.

Itoh H., Tamura K., Izumi M., Motoi Y., Kidoguchi K. \& Funayama Y. 1993. The influence of age and health status and the serum alpha- 1 acid glycoprotein level of conventional and specific pathogen free pigs. Can. J. Vet. Res. 57(2):74-78. PMid:8490810.

Jacobsen S., Niewold T.A., Halling-Thomsen M., Nanni S., Olsen E., Lindegaard C. \& Andersen P.H. 2006. Serum amyloid A isoforms in serum and synovial fluid in horses with lipopolysaccharide-induced arthritis. Vet. Immunol. Immunopathol. 110(3/4):325-330. http://dx.doi.org/10.1016/j. vetimm.2005.10.012. PMid:16337010.

Johanson C.E., Duncan III J.A., Klinge P.M., Brinker T., Stopa E.G. \& Silverberg G.D. 2008. Multiplicity of cerebrospinal fluid functions: new challenges in health and disease. Cerebrospinal Fluid Research 5(1):10. http://dx.doi. org/10.1186/1743-8454-5-10. PMid:18479516.

Kaneko J.J., Harvey J.W. \& Bruss M.L. 2008. Clinical Biochemistry of Domestic Animals. 6th ed. Academic, San Diego. 928p.

Khalil M., Riedlbauer B., Langkammer C., Enzinger C., Ropele S., Stojakovic T., Scharnagl H., Culea V., Petzold A., Teunissen C., Archelos J.J., Fuchs S. \& Fazekas F. 2014. Cerebrospinal fluid transferrin levels are reduced in patients with early multiple sclerosis. Multiple Sclerosis 20(12):15691577. http://dx.doi.org/10.1177/1352458514530020. PMid:24777275.

Laemmli U.K. 1970. Cleavage of structural proteins during the assembly of the head of bacteriophage T4. Nature 227(5259):680-685. http://dx.doi. org/10.1038/227680a0. PMid:5432063.

Lavery K., Way A. \& Killian G. 2003. Identification and immunohistochemical localization of a haptoglobin-like protein in the tissues and fluids of the bovine (Bos taurus) ovary and oviduct. Reproduction 125(6):837-846. http://dx.doi.org/10.1530/rep.0.1250837. PMid:12773106.

Lindqvist D., Hall S., Surova Y., Nielsen H.M., Janelidze S., Brundin L. \& Hansson 0. 2013. Cerebrospinal fluid inflammatory markers in Parkinson's disease: associations with depression, fatigue, and cognitive impairment. Brain, Behavior and Immunity 33:183-189. http://dx.doi.org/10.1016/j. bbi.2013.07.007. PMid:23911592. 
McDonald T.L., Larson M.A., Mack D.R. \& Weber A. 2001. Elevated extrahepatic expression and secretion of mammary-associated serum amyloid A 3 (M-SAA3) into colostrum. Vet. Immunol. Immunopathol. 83(3-4):203-211. http://dx.doi.org/10.1016/S0165-2427(01)00380-4. PMid:11730930.

Mizuno S., Mihara T., Miyaoka T., Inagaki T. \& Horiguchi J. 2005. CSF iron, ferritin and transferrin levels in restless legs syndrome. J. Sleep Res. 14(1):43-47. http://dx.doi.org/10.1111/j.1365-2869.2004.00403.x. PMid:15743333.

Murata H., Shimada N. \& Yoshioka M. 2004. Current research on acute phase proteins in veterinary diagnosis: an overview. Vet. J. 168(1):28-40. http:// dx.doi.org/10.1016/S1090-0233(03)00119-9. PMid:15158206.

Noris-García E., Dorta-Contreras A.J., Escobar-Pérez X. \& González-Hernández M. 1999. Haptoglobin in cerebrospinal fluid as a marker of infectious process in central nervous system. Revta Neurol. 29(2):117-120. PMid:10528321.

Orro T., Jacobsen S., LePage J.P., Niewold T., Alasuutari S. \& Soveri T. 2008. Temporal changes in serum concentrations of acute phase proteins in newborn dairy calves. Vet. J. 176(2):182-187. http://dx.doi.org/10.1016/j. tvjl.2007.02.010. PMid:17412622.

Petersen H.H., Nielsen J.P. \& Heegaard P.M.H. 2004. Application of acute phase protein measurements in veterinary clinical chemistry. Vet. Res. 35(2):163 187. http://dx.doi.org/10.1051/vetres:2004002. PMid:15099494.

Rocha T.G., Nociti R.P., Sampaio A.A.M. \& Fagliari J.J. 2013. Hemogram and acute phase proteins of healthy calves from birth to one month old. Pesq. Vet. Bras. 33(Suppl.1):25-31. http://dx.doi.org/10.1590/S0100736X2013001300005

Roerig A., Carlson R., Tipold A. \& Stein V.M. 2013. Cerebrospinal fluid tau protein as a biomarker for severity of spinal cord injury in dogs with intervertebral disc herniation. Vet. J. 197(2):253-258. http://dx.doi. org/10.1016/j.tvjl.2013.02.005. PMid:23499240.

Roher A.E., Maarouf C.L., Sue L.I., Hu Y., Wilson J. \& Beach T.G. 2009. Proteomicsderived cerebrospinal fluid markers of autopsy confirmed alzheimer's disease. Biomarkers 14(7):493-501. http://dx.doi.org/10.3109/13547500903108423. PMid:19863188.

Sampaio P.H., Fidelis Junior O.L., Marques L.C., Machado R.Z., Barnabé Pde.A., André M.R., Balbuena T.S. \& Cadioli F.A. 2015. Acute-phase protein behavior in dairy cattle herd naturally infected with Trypanosoma vivax. Vet. Parasitol. 211(3/4):141-145. http://dx.doi.org/10.1016/j.vetpar.2015.05.014. PMid:26012859.

Sardella I.G., Singh M., Kumpfer S., Heringer R.R., Saad M.H.F. \& Sohler M.P. 2010. Evaluation of Lionex TB kits and mycobacterial antigens for IgG and IgA detection in cerebrospinal fluid from tuberculosis meningitis patients.
Mem. Inst. Oswaldo Cruz 105(5):722-728. http://dx.doi.org/10.1590/ S0074-02762010000500022. PMid:20835625.

Simplício K.M.M.G., Sousa F.C., Fagliari J.J. \& Silva P.C. 2013. Serum proteinogram emphasizing acute phase proteins from healthy and acute naturally occurring diseased cattle. Arq. Bras. Med. Vet. Zootec. 65(5):1339-1347. http://dx.doi.org/10.1590/S0102-09352013000500011.

Snoeck V., Peters I.R. \& Cox E. 2006. The IgA system: a comparison of structure and function indifferent species. Vet. Res. 37(3):455-467. http://dx.doi. org/10.1051/vetres:2006010. PMid:16611558.

Spooner R.L. \& Miller J.K. 1971. The measurement of haemoglobin reactive protein in ruminants as an aid to the diagnosis of acute inflammation. Vet. Rec. 88(1):2-4. http://dx.doi.org/10.1136/vr.88.1.2. PMid:5099664.

Tizard I.R. 2009. Veterinary Immunology an Introduction. 8th ed. Saunders Elsevier, St Louis, Missouri. 574p.

Wang H., Wang K., Wang C., Zhong X., Qiu W. \& Hu X. 2013. Increased plasma levels of pentraxin 3 in patients with multiple sclerosis and neuromyelitis optica. Multiple Sclerosis 19(7):926-931. http://dx.doi. org/10.1177/1352458512457845. PMid:23012252.

Xie Y., Li Y., Zhang Q., Stiller M.J., Wang C.L.A. \& Streilein J.W. 2000. Haptoglobin is a natural regulator of Langerhans cell function in the skin. J. Dermatol. Sci. 24(1):25-37. http://dx.doi.org/10.1016/S0923-1811(00)00078-5. PMid:10960776.

Yang F., Haile D.J., Berger F.G., Herbert D.C., Van Beveren E. \& Ghio A.J. 2003. Haptoglobin reduces lung injury associated with exposure to blood. Am. J. Physiol., Lung Cell. Mol. Physiol. 284(2):402-409. http://dx.doi. org/10.1152/ajplung.00115.2002. PMid:12388365.

Yang S., Ma Y., Liu Y., Que H., Zhu C. \& Liu S. 2013. Elevated serum haptoglobin after traumatic brain injury is synthesized mainly in liver. J. Neurosci. Res. 91(2):230-239. http://dx.doi.org/10.1002/jnr.23159. PMid:23172820.

Yarchoan M., Louneva N., Xie S.X., Swenson F.J., Hu W., Soares H., Trojanowski J.Q., Lee V.M., Kling M.A., Shaw L.M., Chen-Plotkin A., Wolk D.A. \& Arnold S.E. 2013. Association of plasma C-reactive protein levels with the diagnosis of Alzheimer's disease. J. Neurol. Sci. 333(1/2):9-12. http://dx.doi. org/10.1016/j.jns.2013.05.028. PMid:23978419.

Zhao X., Song S., Sun G., Strong R., Zhang J., Grotta J.C. \& Aronowski J. 2009. Neuroprotective role of haptoglobin after intracerebral hemorrhage. J. Neurosci. 29(50):15819-15827. http://dx.doi.org/10.1523/JNEUROSCI.3776-09.2009. PMid:20016097. 